\title{
OLEANOLIC ACID, A PROSPECTIVE PROTECTIVE AGENT AGAINST BRAIN ENERGY METABOLISM AND OXIDATIVE DYSFUNCTIONS FOLLOWING HEXAVALENT CHROMIUM EXPOSURE IN MICE
}

\author{
SUDIPTA PAL* \\ Nutritional Biochemistry and Toxicology Laboratory, Department of Human Physiology, Tripura University, Suryamaninagar, West \\ Tripura, Tripura, India. E-mail: sudiptapal@tripurauniv.ac.in
}

Received: 05 October 2021, Revised and Accepted: 10 November 2021

\section{ABSTRACT}

Objective: Effect of oleanolic acid against hexavalent chromium-induced altered brain energy metabolism associated with oxidative stress was evaluated in the present study.

Methods: Swiss albino mice were divided into three groups, Control $(n=6)$, chromium-treated $(n=6)$, and oleanolic acid (OA) supplemented ( $\mathrm{n}=6)$. The chromium treated group was orally administered with $\mathrm{K}_{2} \mathrm{Cr}_{2} \mathrm{O}_{7}$ for 30 days at a dose of $10 \mathrm{mg} / \mathrm{kg}$ b.w/day. OA supplementation was given at a dose of $5 \mathrm{mg} / \mathrm{kg}$ bw/day for the past 14 days of chromium treatment. Control group received the vehicle only. After the treatment, whole brain was removed for examining the parameters such as pyruvic acid, free amino nitrogen, tissue protein, TCA cycle enzyme activities, NADH dehydrogenase function, and oxidative stress markers.

Results: Significant decrease in cerebral pyruvic acid content associated with suppressed malate dehydrogenase and succinate dehydrogenase activities were observed. The NADH dehydrogenase activity was inhibited owing to enhanced accumulation of chromium in cerebral tissue. Depletion of proteins and increased free amino acid nitrogen were accompanied with inhibited cathepsin, pronase and trypsin activities, and increased transaminase function. In addition, GSH content was decreased along with increased lipid peroxidation, oxidized GSSG content, TG/GSSG ratio, carbonylated protein content, and tissue free hydroxyl radical formation. Superoxide dismutase, catalase, glutathione reductase, and glutathione peroxidase were also inhibited by hexavalent chromium. Oleanolic acid supplementation was found to have significant protective effect against brain metabolic and oxidative dysfunctions.

Conclusion: The present study elucidated therapeutic efficacy of oleanolic acid against hexavalent chromium toxicity in brain tissue of mice.

Keywords: Hexavalent chromium, Glycolysis, TCA cycle, Protease activity, Oxidative stress, Oleanolic acid, Natural antioxidant.

(c) 2021 The Authors. Published by Innovare Academic Sciences Pvt Ltd. This is an open access article under the CC BY license (http://creativecommons.org/ licenses/by/4.0/) DOI: http://dx.doi.org/10.22159/ajpcr.2021v14i12.43311. Journal homepage: https://innovareacademics.in/journals/index.php/ajpcr

\section{INTRODUCTION}

Metal toxicity is one of the serious problems to living organisms as a consequence of industrialization, globalization, pollution, and other anthropogenic activities. Its extensive applications including plating, painting, leather tanning, cementing and as anticorrosion agent make it more available for human exposure [1]. In environment, it exists in different valency states, among which hexavalent chromium is hemotoxic, carcinogenic and mutagenic in nature [2,3]. Due to solubility in water, hexavalent chromium is abundant in polluted water. The maximum permissible limit for hexavalent chromium in drinking water is $0.05 \mathrm{mg} / \mathrm{l}$ as per WHO recommendation. Other common route of exposure is inhalation through paint dusts, aerosol and color pigments [4]. Seven countries in the world namely South Africa, India, Zimbabwe, Kazakhstan, Brazil, Finland, and Turkey experience chromium exposure from human activities at stationary point sources [5].

The toxic effect of hexavalent chromium exhibits when it rapidly crosses the biological membrane, enters the cell and is converted to trivalent chromium; otherwise, reduction of hexavalent chromium outside the cell is found to be less toxic [6]. Respiratory distress is the most common symptom for chromate sensitive workers acutely exposed to hexavalent chromium. Other organ systems such as cardiovascular, hematological, nervous, gastrointestinal, reproductive, immunological, and renal systems are also adversely affected by chronic and acute chromium exposure [6]. The molecular mechanism of hexavalent chromium toxicity involves generation of free radicals and highly reactive chromium intermediates [7]. Brain tissue is highly susceptible to oxidative stress due its high lipid content and high oxygen consumption for its metabolic purpose. Enhanced lipid peroxidation in brain tissue of mammals was noted in an earlier study [8]. Chrome plating plant workers when exposed to chromium trioxide fumes, often experience headache, dizziness and weakness [6], indicating harmful neurological effects of chromium in human. Further study confirmed that $\mathrm{Cr}$ (VI) is a potent neurotoxic agent for the matured neuronal cell and altered brain physiochemical functioning [9].

In a number of studies, it is established that over-exposure of hexavalent chromium is associated with its significant deposition in the rat hypothalamus, anterior pituitary, hepatic as well as muscular tissue [10]. Excessive accumulation of this metalloid may lead to metabolic complications in exposed organisms. Inadequate information regarding detailed metabolic toxicity by hexavalent chromium raised the curiosity about this compound and thus aimed at determining its mechanism of action on metabolic profile. Limited evidences are there in support of metabolic toxicity by $\mathrm{Cr}$ (VI) [11,12]. In a stressed tissue, it is very much expected that metabolites involved in energy yielding biochemical processes may be influenced by the stressor. Chromium, being an oxidative stress producing metalloid may have certain adverse effects on metabolic profile of the soft tissue like brain. The present study thus tried to explore plausible mechanism related to TCA cycle, oxidative phosphorylation and the protein metabolic efficacy along with certain oxidative stress markers in the highly energetic cerebral tissue in presence of excess hexavalent chromium. 
Natural antioxidants have important roles in ameliorating environmental pollutant-induced cellular damage. Among certain polyphenolic antioxidants, oleanolic acid $(\mathrm{OA})$ has gained attention due to its beneficial effect against metal/metalloid encouraged metabolic toxicity in vivo [13]. Oleanolic acid, or 3 $\beta$-hydroxyolean-12-en-28-oic acid, is a pentacyclic triterpenoid found naturally in certain leaves, fruits, and plants. Being a non-toxic and hepatoprotective agent against chemical-induced fatty liver diseases, it attained its importance in pharmacotherapy [14]. Protective functions of oleanolic acid such as, antitumor, antidiabetic, hepatoprotective, anti-inflammatory, antioxidant, and antibacterial activities were addressed in different animal models [13,15-17].

Earlier studies revealed that oleanolic acid served as a protective agent against sodium fluoride induced alteration in brain protein and nucleic acid metabolism and was suggested as a prospective neuroprotective agent against fluoride toxicity [13]. Oxidative damage caused by sub-acute fluoride toxicity was appreciably corrected by oleanolic acid in vivo, signifying its antioxidant property to improve cellular functions [13]. Antioxidant efficacy of oleanolic acid was mediated by its superoxide radical trapping activity, inhibition of xanthine oxidase activity and metal ion chelating property [18]. Accordingly, the present study aims at determining the effect of oleanolic acid supplementation in hexavalent chromium treated brain tissue of mice, to evaluate whether this triterpenoid has any efficacy to counteract chromiuminduced metabolic alteration in brain tissue, or not.

\section{MATERIALS AND METHODS}

\section{Materials}

All chemicals and reagents, such as hemoglobin, trichloroacetic acid (TCA), dimethyl sulfoxide (DMSO), 5,5'-DTNB, potassium dichromate $\left(\mathrm{K}_{2} \mathrm{Cr}_{2} \mathrm{O}_{7}\right)$, bovine serum albumin (BSA), EDTA, $\mathrm{H}_{2} \mathrm{O}_{2}, \mathrm{NADH}, \mathrm{NADPH} . \mathrm{Na}_{2}$, methanol, ethanol, Fat blue BB salt, glutathione (GSH), thiobarbituric acid (TBA), and sodium carbonate, were of analytical grade and purchased from Merck (India), SRL (India), Sigma-Aldrich (India). Biochemical kits such as GPT, GOT were purchased from Coral clinical systems. TG/GSSG colorimetric assay kit (Elabscience), distilled water prepared by Millipore water purifier was used throughout the experiment to avoid metal contamination.

\section{Isolation and extraction of oleanolic acid from Neanotis wightiana plant}

N. wightiana is a medicinal plant found in Tripura, collected from Kalsi, Jolaibari, South Tripura and identified by Prof. B.K. Datta, Taxonomist, Department of Botany, Tripura University. Voucher specimen (\#BD/02/08) was deposited in the National Herbarium, Botanical Survey of India, botanical garden, Howrah, West Bengal, India. The aerial part of this plant was claimed to have therapeutic effect on liver and brain damage by the local people of Tripura.

The plant extract was prepared by the method of Das et al. [19]. In brief, the aerial part of N. wightiana was air-dried and extracted with methanol (10Lx3, 1 week each) at room temperature. The extract was concentrated with reduced pressure in vacuo to obtain a semi-solid mass $(400 \mathrm{~g})$. The residue was then suspended in $125 \mathrm{ml}$ of triple distilled water and further extracted with hexane, chloroform, ethyl acetate, and n-butanol (three times each, $200 \mathrm{ml}$ ). The ethyl acetate extract (20.2 g) was column chromatographed through silica gel and eluted with stepwise gradient of CHCl3/EtOAc (100:0, 90:10, 80:20, $70: 30,60: 40,50: 50,40: 60,20: 80,10: 90$ each $500 \mathrm{ml})$. The fraction eluted with $\mathrm{CHCl} 3 / \mathrm{EtOAc}$ (70:30) formed a gummy residue which was again subjected to column chromatography with silica gel and finally

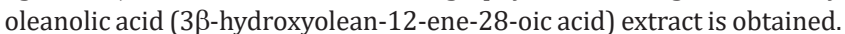

\section{Selection of animals}

To conduct the present experiment, Swiss albino male mice $(n=18)$ weighing 35-40 g were purchased from Chakraborty Enterprise (Reg.No.1443/PO/b/11/CPCSEA), Kolkata, India, an authorized animal supplier nominated by CPCSEA, Ministry of Environment and
Forests, Govt. of India. Drinking water was given to the animals adlibitum throughout the treatment schedule. The mice were kept in the treatment room with sustaining $22-25^{\circ} \mathrm{C}$ temperature and humidity $(50 \%)$ with alternate light and dark coverage for $12 \mathrm{~h}$.

\section{Experimental design}

Total eighteen numbers of healthy and equal average sized body weight (30-35 g) of mice were taken for the present study and divided into three groups namely control group, $\mathrm{Cr}(\mathrm{VI})$-treated group, and OA-supplemented group, each having six $(n=6)$ numbers of animals in each group.

\section{Control group}

Mice received drinking water orally.

\section{$\mathrm{Cr}$ (VI)-treated group}

The animals of this group were treated with $\mathrm{Cr}$ (VI) (as potassium dichromate, $\mathrm{K}_{2} \mathrm{Cr}_{2} \mathrm{O}_{7}$ at a dose of $10 \mathrm{mg} / \mathrm{kg}$ b.w/day orally by oro-gastric feeding needle for a period of 30 days). The dose had been selected on the basis of a dose-dependent study performed earlier which revealed that at the mentioned dose significant alteration in certain parameters related to carbohydrate metabolism in hepatic tissue was found without causing any casualty to the animals [20]. Moreover, the selected dose of $\mathrm{Cr}$ (VI) was also used in earlier occasions [21,22].

\section{OA-supplemented group}

Hexavalent chromium as potassium dichromate was administered at $10 \mathrm{mg} / \mathrm{kg}$ bw/day orally for 30 days along with oleanolic acid (OA) supplementation at a dose of $5 \mathrm{mg} / \mathrm{kg}$ bw/day for the past 14 days of chromium treatment. The dose of oleanolic acid was selected on the basis of earlier report [13].

\section{Animal sacrifice}

At the end of the treatment, the mice were sacrificed by cervical dislocation as per the rules and regulations of the Institutional Animal Ethical Committee. Ethical approval for the present work was received by the Institutional Animal Ethical Committee, Tripura University [Approval no. TU/IAEC/2015/XI/2-3 dated 28 $8^{\text {th }}$ July, 2015]. Thereafter, whole brain was dissected out from the animals, washed in ice-cold saline $(0.9 \% \mathrm{NaCl})$, blotted dry, weighed and kept at $-20^{\circ} \mathrm{C}$ until biochemical analyzes were performed.

\section{Preparation of tissue homogenate}

The $5 \%$ (mass/volume) brain tissue homogenate was prepared in $0.1 \mathrm{M}$ phosphate buffer (pH 7.4) using all glass homogenizer and kept frozen at $-20^{\circ} \mathrm{C}$ until biochemical analyzes were performed.

Preparation of mitochondrial isolate for estimation of the TCA cycle enzymes

In brief, $500 \mathrm{mg}$ of the brain tissue was kept in $10 \mathrm{ml}$ of sucrose buffer [containing $0.25 \mathrm{M}$ sucrose, $0.001 \mathrm{M}$ EDTA, $0.05 \mathrm{M}$ Tris $\mathrm{HCl}(\mathrm{pH}$ 7.8)] at $25^{\circ} \mathrm{C}$ for 5 minutes. It was then homogenized in ice-cold chamber (at $4^{\circ} \mathrm{C}$ ) for ten minutes at $1500 \mathrm{rpm}$ using a Potter Elvenjem glass homogenizer. The supernatant was recentrifuged at $4000 \mathrm{rpm}$ for 5 minutes at $4^{\circ} \mathrm{C}$. The supernatant was further centrifuged at $14000 \mathrm{rpm}$ for 20 minutes at $4^{\circ} \mathrm{C}$. The final supernatant was discarded and the pellet was re-suspended in sucrose buffer and kept at $-20^{\circ} \mathrm{C}$ for biochemical analyses. Freshly prepared mitochondrial isolate was used for the experiment [23].

\section{Morpho-physiological analyzes}

Body weight and cerebro-somatic index (CSI)

The body weight of the mice of each group was taken from the first day of treatment and recorded periodically until sacrifice. The organ weight (whole brain) of the respective group of mice was noted after sacrifice of the animals. The cerebro-somatic index (CSI) was calculated as follows [24].

$$
\text { Organo }- \text { somatic index }=\frac{\text { Weight of the whole brain }(g)}{\text { Day30thtotal body weight }(g)} \times 100
$$


Biochemical analyses

Pyruvic acid level

The 5\% brain tissue homogenate was centrifuged with 5\% TCA at $3000 \mathrm{rpm}$ for 10 minutes. The supernatant was treated with $0.5 \mathrm{ml}$ 2,4-DNPH and $1 \mathrm{ml}$ of distilled water and mixed vigorously for approximately 3 minutes. Toluene was added and mixed by hand shaking for a few minutes. It was then added with $2 \mathrm{ml}$ of $\mathrm{Na}_{2} \mathrm{CO}_{3}$ and $\mathrm{NaOH}$ solution each to measure the optical density at $420 \mathrm{~nm}$ in a spectrophotometer. The observed result was expressed as $\mu \mathrm{g} / \mathrm{g}$ of tissue [25].

\section{Succinate dehydrogenase (SDH) activity}

The SDH activity was measured spectrophotometrically by the reduction of potassium ferricyanide $\left(\mathrm{K}_{3} \mathrm{Fe}(\mathrm{CN})_{6}\right)$ at $420 \mathrm{~nm}$ [23]. One millilitre of the assay mixture contained $0.05 \mathrm{M}$ phosphate buffer ( $\mathrm{pH} 7.4$ ), 2\% BSA (w/v), $4 \mathrm{mM}$ succinate, $2.5 \mathrm{mM} \mathrm{K}_{3} \mathrm{Fe}(\mathrm{CN})_{6}$ and a definite volume of the mitochondrial isolate (enzyme source). The enzyme activity was expressed as unit/min/mg of protein.

\section{Malate dehydrogenase (MDH) assay}

The assay mixture contained potassium phosphate buffer, $76 \mathrm{mM}$ oxaloacetic acid and $5 \mathrm{mM} \mathrm{NADH}$ at $\mathrm{pH}$ 7.4. The reduction of NADH was measured at $340 \mathrm{~nm}$ for 5 minutes by observing change in optical density at each 10 second interval. The enzyme activity was expressed as mmoles of NADH oxidized/min/mg of protein [26].

\section{Assay of NADH: Ubiquinone C oxidoreductase activity}

The assay mixture consisted of $1 \mathrm{ml}$ phosphate buffer, $0.1 \mathrm{ml} \mathrm{K} \mathrm{Fe}_{3}(\mathrm{CN})_{6}$ and $0.2 \mathrm{ml}$ of mitochondrial suspension in a total volume of $3 \mathrm{ml}$ with distilled water. Freshly prepared $0.1 \%$ NADH solution was added just before the addition of the mitochondrial isolate except the blank set. The change in optical density was measured at $420 \mathrm{~nm}$ for 3 minutes. The enzyme activity was expressed as mmoles of NADH oxidized/min/ mg of protein [27].

\section{Protein carbonylation}

Briefly, the samples were mixed with the same volume of $10 \mathrm{mM} \mathrm{2,4-}$ DNPH reagent prepared in $2.5 \mathrm{M} \mathrm{HCl}$ and incubated for half an hour at room temperature by vigorous shaking at each 15 minutes interval. The samples were then treated with 20\% TCA and kept in ice for a while. It was then centrifuged at low r.p.m, and the pellet was taken. The pellet was washed with ethanol/ethyl acetate mixture $(1: 1 \mathrm{v} / \mathrm{v})$ twice and finally dissolved in $6 \%$ SDS and centrifuged again. The optical density of the supernatant was recorded at $370 \mathrm{~nm}$. The results were expressed as nmoles of DNPH-incorporated/mg protein. The molar extinction coefficient of $22,000 / \mathrm{M} / \mathrm{cm}$ was used for the final calculation of the carbonylated protein content [28].

\section{Free amino nitrogen content}

The tissue homogenate was mixed with $2 / 3 \mathrm{~N} \mathrm{H} 2 \mathrm{SO} 4$ and $10 \%$ sodium tungstate for precipitation of tissue proteins. The protein free aliquot was treated with cyanide-acetate buffer and 3\% ninhydrin solution and mixed thoroughly. The mixture was heated in a boiling water bath for 5 minutes. Immediately after cooling, isopropyl alcohol was added to the mixture. A violet color was developed, the absorbance was read at $570 \mathrm{~nm}$ in a spectrophotometer. Free amino nitrogen level was expressed in $\mathrm{mg} / \mathrm{g}$ of tissue [29]

\section{Pronase activity}

The $5 \%$ tissue homogenate (in $0.1 \mathrm{M} \mathrm{PB}, \mathrm{pH} 7.4$ ) was mixed with casein substrate and incubated at $40^{\circ} \mathrm{C}$ for 30 minutes. The reaction was terminated by protein precipitating reagent. The mixture was then centrifuged to obtain clear supernatant, and the absorbance of which was read at $280 \mathrm{~nm}$ in an UV-visible spectrophotometer. Pronase activity was expressed as nmoles of tyrosine formed $/ \mathrm{min} / \mathrm{mg}$ protein [30].
Trypsin activity

A definite volume of $5 \%$ tissue homogenate was taken in a sample tube and added with $2.5 \mathrm{ml}$ of hemoglobin substrate, followed by incubation at $25^{\circ} \mathrm{C}$ for 30 minutes. A buffer blank was prepared by taking trichloroacetic acid (TCA), then followed by addition of tissue sample and the substrate. After incubation, 5\% TCA was added to the sample tube to stop the reaction. All the tubes were centrifuged to obtain protein free filtrate. The absorbance of the final aliquot was taken in an UV-visible spectrophotometer at $280 \mathrm{~nm}$. The enzyme activity was calculated as nmoles of tyrosine produced/min/mg protein [31]

Cathepsin activity

The $5 \%$ tissue homogenate (in $0.1 \mathrm{M} \mathrm{PB}, \mathrm{pH} 7.4$ ) was added with $4 \%$ hemoglobin substrate and incubated at $37^{\circ} \mathrm{C}$ for 60 minutes. After incubation, reaction was stopped by addition of $8 \%$ TCA. A buffer blank was prepared in a same manner in which TCA was added before addition of the tissue homogenate and the Hb substrate. All the tubes were then centrifuged to obtain protein free clear supernatant. Absorbance of the supernatant was taken at $280 \mathrm{~nm}$ wavelength using an UV-visible spectrophotometer. Tissue cathepsin activity was expressed in terms of nmoles of tyrosine produced/min/mg protein [32].

Glutamate pyruvate transaminase (GPT) and glutamate oxaloacetate transaminase (GOT) activities

The assay was done with the help of a standard kit (Coral clinical system, Goa, India). After completion of overall reaction, readings were taken in a spectrophotometer at $505 \mathrm{~nm}$ wavelength. The enzyme activity was expressed in terms of units/g of tissue [33].

\section{Reduced glutathione (GSH) content}

Reduced glutathione content in brain tissue of mice was measured using Ellman's reagent [34]. The 5\% tissue homogenate in $0.1 \mathrm{M} \mathrm{PB}$, pH 7.4 was mixed with $20 \%$ TCA containing 1 mM EDTA to precipitate proteins. The supernatant was mixed with Ellman's reagent and kept for 20 minutes at room temperature. The absorbance was read at $412 \mathrm{~nm}$. The GSH content was expressed in terms of $\mu$ moles/mg protein.

\section{Tissue total glutathione/oxidized glutathione ratio (TG/GSSG)}

The TG/GSSG ratio was estimated in the cerebral tissue of mice by colorimetric assay kit (Elabscience) [35]. The estimation was based on oxidation-reduction reaction using DTNB. GSSG was reduced to GSH by glutathione reductase, and GSH was oxidized by DTNB to produced GSSG and a yellow TNB. The amount of TNB represented total glutathione (GSSG+GSH), the absorbance of which was read at $412 \mathrm{~nm}$. The content of GSSG was determined by first removing GSH from the sample with suitable reagent followed by the above-mentioned reaction principle.

\section{Tissue lipid peroxidation (LPO) level}

In brief, the $5 \%$ tissue homogenate in $0.1 \mathrm{M} \mathrm{PB}, \mathrm{pH} 7.4$ was mixed with $20 \%$ TCA and thiobarbituric acid. The reaction mixture was then mixed with $1 \mathrm{mM}$ EDTA. The mixture was heated at $80^{\circ} \mathrm{C}$ for 5 minutes. Absorbance of the final reaction mixture was taken at $533 \mathrm{~nm}$ in a spectrophotometer. The molar extinction co-efficient, $1.56 \times 10^{5} \mathrm{~cm}^{2} / \mathrm{mmol}$ of malondialdehyde was used to calculate the LPO level [36].

\section{Tissue free hydroxyl radical formation}

At first, all of the mice were treated with 30\% DMSO $(0.4 \mathrm{ml} / 100 \mathrm{~g} \mathrm{bw})$ two hours before sacrifice of the animals. After sacrifice, $5 \%$ brain tissue homogenate was prepared in triple distilled water for determination of free hydroxyl radical generation [37]. The tissue homogenate was added with $10 \mathrm{~N} \mathrm{H}_{2} \mathrm{SO}_{4}$ to precipitate proteins. The filtrate was taken for extraction of methane sulfinic acid, which was produced from DMSO by the reaction with free hydroxyl radicals. The mixture was then treated with fast blue BB salt to obtain a yellow color adduct, the absorbance of which was measured in a spectrophotometer at $425 \mathrm{~nm}$. 
Catalase (CAT) activity

The $5 \%$ brain tissue homogenate (in $0.1 \mathrm{M}$ phosphate buffer, $\mathrm{pH} 7.4$ containing $1 \%$ triton $\mathrm{X}-100$ ) was taken for estimation of the catalase activity [38]. The rate of degradation of $\mathrm{H}_{2} \mathrm{O}_{2}$ was measured as the enzyme catalyzed reaction. The enzyme activity was expressed in terms of micromoles of $\mathrm{H}_{2} \mathrm{O}_{2}$ utilized/minute/mg protein.

\section{Superoxide dismutase (SOD) activity}

The $5 \%$ brain tissue homogenate (in $0.1 \mathrm{M} \mathrm{PB}, \mathrm{pH} 7.4$ ) was centrifuged at $10,000 \mathrm{~g}$ for 10 minutes. The collected aliquot was taken for estimation of the SOD activity [39]. The increase in rate of auto-oxidation of hematoxylin in aqueous alkaline solution was noted after addition of enzyme solution. The chromophore produced due to the reaction was read at $560 \mathrm{~nm}$ in a spectrophotometer. The SOD activity was expressed as units/minute/mg of protein.

\section{Glutathione reductase (GR) activity}

The assay medium contained $0.2 \mathrm{M}$ phosphate buffer ( $\mathrm{pH} 7.0$ containing $2 \mathrm{mM}$ EDTA), $20 \mathrm{mM}$ GSSG and $2 \mathrm{mM}$ NADPH and the tissue sample. The enzyme activity was measured at $25^{\circ} \mathrm{C}$ at $340 \mathrm{~nm}$ wavelength in an UVvisible spectrophotometer. The disappearance of NADPH was recorded at $30 \mathrm{sec}$ intervals and the activity was expressed in terms of NADPH oxidized per minute per mg of protein [40]

Glutathione peroxidase (GPX) activity

The $10 \%$ brain tissue homogenate (in $0.1 \mathrm{M} \mathrm{PB}, \mathrm{pH} 7.4$ ) was centrifuged at $10,000 \mathrm{~g}$ for $30 \mathrm{~min}$ at $4^{\circ} \mathrm{C}$. The clear supernatant was used as sample for estimation. The reaction mixture consisted of definite volume of 0.1 M PB, pH 7.4, $10 \mathrm{mM} \mathrm{GSH}, 0.2$ units glutathione reductase and $50 \mu \mathrm{L}$ of the sample. The mixture was incubated at $37^{\circ} \mathrm{C}$ for $10 \mathrm{~min}$ followed by addition of $1.5 \mathrm{mM}$ NADPH. The absorbance was recorded at $340 \mathrm{~nm}$ wavelength. The enzyme activity was represented as nmoles of NADPH oxidized per min per mg protein [41]

\section{Tissue protein content}

The tissue protein content was estimated according to the method of Lowry et al. [42]. Protein content was expressed as g/100 g of tissue.

Tissue Cr (VI) analysis

Tissue $\mathrm{Cr}$ (VI) content of brain tissue was determined using atomic absorption spectrometer (Perkin Elmer A Analyst 700) according to the method suggested by Sun and Liang [43]. Data were expressed as $\mu \mathrm{g} / \mathrm{g}$ tissue.

\section{Statistical analyses of data}

The obtained data were expressed as means \pm SEM. One-way ANOVA was used for analyses of data followed by 'multiple comparison t-test' for comparison between the two groups. $\mathrm{p}<0.05$ was considered statistically significant.

\section{RESULTS}

There was insignificant change $(6 \%$ decrease; $p>0.05)$ in the body weight of the $\mathrm{Cr}(\mathrm{VI})$-treated mice compared to the control group at the present dose and duration (Table 1). The cerebro-somatic index
(CSI) was significantly increased $(32 \%, \mathrm{p}<0.05)$ following $\mathrm{Cr}$ (VI) treatment. $\mathrm{Cr}$ was accumulated in the brain tissue at high amount (ten folds increase, $\mathrm{p}<0.001$ ) in comparison to the respective control value (Table 1). Oleanolic acid supplementation in chromium-treated mice appreciably restored the changes in CSI $(21.3 \%$ restoration, $\mathrm{p}<0.05)$ and tissue chromium concentration $(30.7 \%$ restoration, $\mathrm{p}<0.001)$, when co-treated with hexavalent chromium (Table 1), whereas body weight of the mice remained almost unaltered in the OA-supplemented group.

It was revealed from the Fig. 1 that the malate dehydrogenase activity was decreased by $48.2 \%(p<0.001)$ following exposure to hexavalent chromium $(\mathrm{p}<0.001)$. OA supplementation was found to be protective to some extent to restore the MDH activity in mice brain. The counteraction was noted to be $35 \%$ in respect to the chromium-treated group of mice $(\mathrm{p}<0.001)$.

The activity of the succinate dehydrogenase, another TCA cycle enzyme was also decreased significantly $(\mathrm{p}<0.001)$ following exposure to hexavalent chromium (Fig. 2). OA supplementation in chromium exposed mice appreciably counteracted the brain SDH activity by $53.2 \%$ of the control value $(\mathrm{p}<0.001)$

It was observed from Fig. 3 that the activity of mitochondrial complex 1 (NADH dehydrogenase) was reduced by $35.8 \%(p<0.01)$ in mice brain owing the toxic effect of $\mathrm{Cr}$ (VI). Oleanolic acid supplementation in chromium exposed mice partially counteracted the mitochondrial complex 1 activity. The restoration was found to be $84.2 \%$ of the control value.

Change in total protein content revealed that $\mathrm{Cr}$ (VI) treatment increased total protein content in the cerebral tissue by $24.2 \%(\mathrm{p}<0.05)$ (Table 2). Oleanolic acid supplementation checked brain protein enhancement

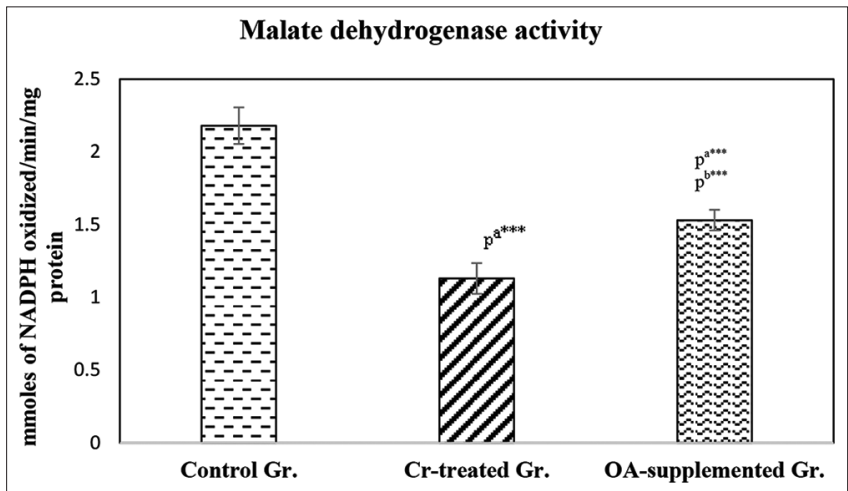

Fig. 1: Protective effect of oleanolic acid on chromium induced decreased MDH enzyme activity in mice brain. Values were expressed as Means \pm SEM Each bar represents mean value of data from six number of mice. Asterisk indicates significant difference level. pa compared with control group, pb compared with chromium treated group. ${ }^{* * *}$ considered statistically highly significant $(p<0.001)$

Table 1: Body weight, CSI and bio-distribution of $\mathrm{Cr}$ (VI) in brain tissue of mice exposed to $\mathrm{Cr}$ (VI) with or without $\mathrm{OA}$ supplementation

\begin{tabular}{llll}
\hline Groups of animals (n=18) & Final body weight $(\mathbf{g})$ after $\mathbf{3 0}$ days & Cerebro-somatic index & $\begin{array}{l}\text { Bio-distribution of Cr }(\mathrm{VI}) \text { in brain tissue( } \boldsymbol{H g} / \mathbf{g} \\
\text { of tissue) }\end{array}$ \\
\hline Control $(\mathrm{n}=6)$ & $36.33 \pm 1.75$ & $0.41 \pm 0.03$ & $1.73 \pm 0.08$ \\
Cr-Treated $(\mathrm{n}=6)$ & $34.13 \pm 1.31^{\#}$ & $0.54 \pm 0.024^{\mathrm{pa} *}$ & $17.5 \pm 1.56^{\mathrm{pa} * * *}$ \\
OA-supplemented $(\mathrm{n}=6)$ & $35.26 \pm 1.06^{\#}$ & $0.425 \pm 0.018^{\mathrm{p} *}$ & $12.12 \pm 1.84^{\mathrm{p} * * *}$ \\
\hline
\end{tabular}

Figures in the parentheses indicate number of animals in each group ( $\mathrm{n}=6)$. N represents total number of animals. Values are expressed as Means \pm SD. $\# p>0.05$ (Not significant), pa compared to control group and pb compared with Cr-treated group. ${ }^{*} \mathrm{p}<0.05 ;{ }^{* *} \mathrm{p}<0.01$ and ${ }^{* * *} \mathrm{p}<0.001$ are considered statistically significant. Control group received drinking water only, Cr-treated group was treated with hexavalent chromium at a dose of $10 \mathrm{mg} / \mathrm{kg}$ b.w./day for a period of thirty days and oleanolic acid supplemented group received chromium at the mentioned dose and $\mathrm{OA}$ at a dose of $5 \mathrm{mg} / \mathrm{kg}$ b.w./day orally for last two weeks of chromium exposure. 
partially $(9.6 \%$ counteraction, $\mathrm{p}<0.05)$. Pyruvic acid content was significantly decreased in brain tissue by $63.41 \%(\mathrm{p}<0.01)$ due to $\mathrm{Cr}$ (VI) toxicity (Table 2). Oleanolic acid supplementation moderately counteracted ( $50 \%$ of the control value) chromium induced decrease in brain pyruvic acid content. It was further noted that $\mathrm{Cr}$ (VI) exposure increased the level of free amino nitrogen by almost three folds $(\mathrm{p}<0.001)$; GPT and GOT activities were increased by $52.2 \%(\mathrm{p}<0.001)$ and $45 \%(p<0.001)$, respectively, in chromium exposed brain tissue (Table 2). Administration of oleanolic acid in chromium-treated mice appreciably restored the increased free amino acid nitrogen content as well as transaminase enzyme activities toward normalcy.

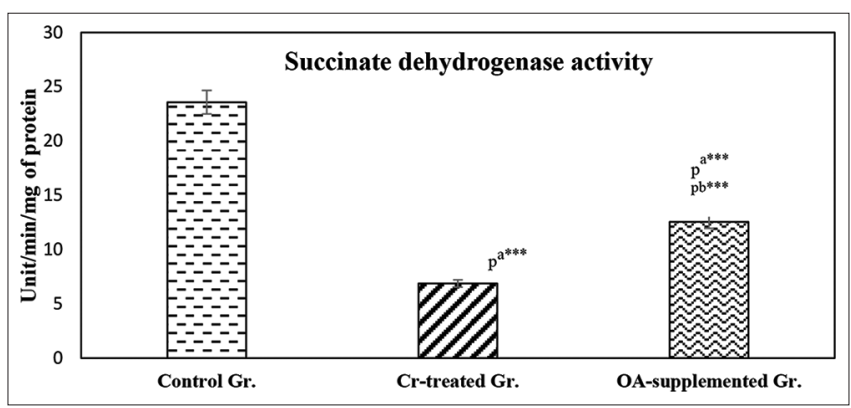

Fig. 2: Counteractive effect of oleanolic acid on chromium induced decrease in SDH enzyme activity in mice brain. Values are expressed as Means \pm SEM. Each bar represents mean value of data from six numbers of mice. Asterisk indicates significant difference level. pa compared with control group, pb compared with chromium treated group. ${ }^{* * *}$ Considered statistically highly significant $(\mathrm{p}<0.001)$.

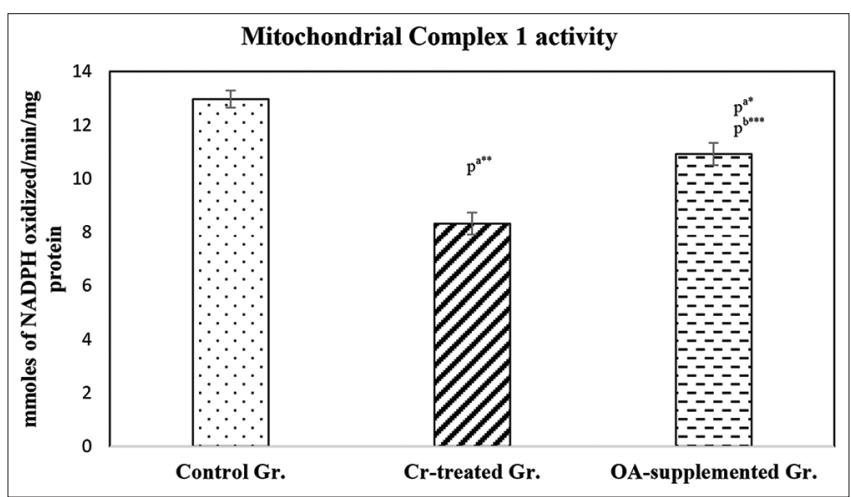

Fig. 3: Effect of $\mathrm{Cr}$ (VI) on mitochondrial Complex 1 (NADH dehydrogenase) activity in brain tissue of mice with or without oleanolic acid supplementation. Values were expressed as Means \pm SEM. Each bar represents mean value of data from six numbers of mice. Asterisk indicates significant difference. pa compared with control group, pb compared with chromium treated group. ${ }^{* * *}$ Considered statistically highly significant $(\mathrm{p}<0.001)$ and ${ }^{* *}$ indicated $\mathrm{p}<0.01$
Protein carbonylation was an important marker of the oxidative damage of proteins. In the present study, carbonylated protein content was significantly elevated after chromium treatment (Fig. 4). The increase was recorded as $49.5 \%(\mathrm{p}<0.01)$ of the control value. OA supplementation partially restored the level of carbonylated proteins in chromium-exposed mice brain. The restoration was found to be $23.1 \%$ $(\mathrm{p}<0.05)$.

Different proteolytic enzyme activities of the brain tissue of mice were significantly varied in response to the $\mathrm{Cr}(\mathrm{VI})$ toxicity (Fig. 5). Pronase, cathepsin, and trypsin activities were decreased by 32.05\% ( $<<0.01)$, $18.8 \%(\mathrm{p}<0.05)$, and $58 \%(\mathrm{p}<0.001)$, respectively after chromium exposure. Oleanolic acid supplementation counteracted chromiuminduced change in pronase activity by $83 \%$, cathepsin activity by $100 \%$ and trypsin activity by $81 \%$ of the respective control values.

Cellular antioxidant status revealed that hexavalent chromium exposure abruptly affected both enzymatic and non-enzymatic antioxidants after scheduled duration of exposure (Table 3). It was revealed that brain glutathione content was decreased by $41.15 \%(\mathrm{p}<0.001)$ by hexavalent chromium exposure. Oleanolic acid supplementation restored the decreased GSH content by 55\% in respect of the $\mathrm{Cr}$ (VI)-treated group. Chromium exposure significantly increased (almost 99\%, p<0.001) the GSSG content in brain tissue of mice, which was restored by $28 \%(\mathrm{p}<0.05)$ by oleanolic acid supplementation. Additionally, total glutathione/oxidized glutathione ratio (TG: GSSG) was remarkably decreased $(47.3 \%, \mathrm{p}<0.001)$ in chromium exposed mice brain. Oleanolic acid supplementation partially restored the TG: GSSG ratio (76\% restoration) toward the control value. Chromium exposure caused significant elevation of lipid peroxidation in cerebral tissue of mice. The elevation was recorded as $55.8 \%$ in comparison to the control value. Oleanolic acid appreciably checked chromium-induced increased

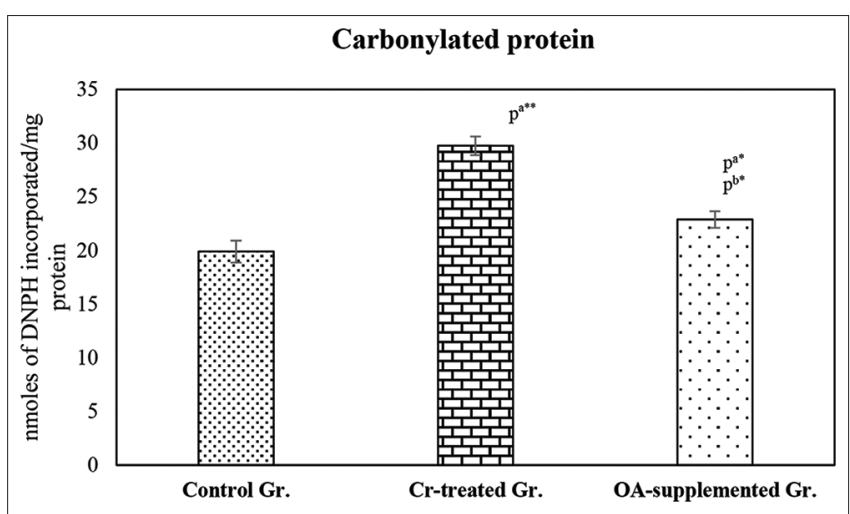

Fig. 4: Counteractive effect of $\mathrm{OA}$ against $\mathrm{Cr}$ (VI) induced elevated carbonylated protein content in brain tissue of mice. Values were expressed as Means \pm SEM. Each bar represents mean value of data from six numbers of mice. Asterisk indicates significant difference. pa compared with control group, pb compared with chromium treated group. *and **Considered statistically significant $(\mathrm{p}<0.05, \mathrm{p}<0.01$, respectively)

Table 2: Protective effect of oleanolic acid (OA) on Cr (VI)-induced alteration in brain total protein content, pyruvic acid level, free amino acid nitrogen (FAAN) content and transaminase enzyme (GOT and GPT) activities

\begin{tabular}{|c|c|c|c|c|c|}
\hline Groups of animals $(\mathrm{N}=18)$ & $\begin{array}{l}\text { Total protein } \\
\text { (g/100g tissue) }\end{array}$ & Pyruvic acid ( $\mu \mathrm{g} / \mathrm{g}$ tissue) & FAAN (mg/g tissue) & GOT activity (U/g tissue) & $\begin{array}{l}\text { GPT activity } \\
\text { (U/g tissue) }\end{array}$ \\
\hline Control $(n=6)$ & $9.22 \pm 0.15$ & $198.26 \pm 6.35$ & $0.98 \pm 0.07$ & $80.5 \pm 2.63$ & $36.14 \pm 3.87$ \\
\hline Cr-treated $(n=6)$ & $11.45 \pm 0.18^{\mathrm{p} *}$ & $72.54 \pm 4.32^{\text {ра** }}$ & $2.96 \pm 0.34$ pa*** & $117 \pm 4.34^{\mathrm{pa} * * *}$ & $55 \pm 1.88^{\text {pa*** }}$ \\
\hline OA-Supplemented $(n=6)$ & $10.35 \pm 0.382^{\mathrm{pb} *}$ & $100.12 \pm 2.36^{\mathrm{pb} * * *}$ & $1.65 \pm 0.08^{\mathrm{pb} * * *}$ & $93.83 \pm 1.42^{\mathrm{pb} * *}$ & $42.93 \pm 1.76^{\mathrm{pb} * * *}$ \\
\hline
\end{tabular}

Figures in the parentheses indicate number of animals in each group $(n=6)$. $\mathrm{N}$ represents total number of animals. Values are expressed as Means \pm SEM. pa compared to control group and pb compared with Cr-treated group. ${ }^{*} \mathrm{p}<0.05 ;{ }^{* *} \mathrm{p}<0.01$ and ${ }^{* * *} \mathrm{p}<0.001$ are considered statistically significant. Control group received drinking water only, Cr-treated group was treated with hexavalent chromium at a dose of $10 \mathrm{mg} / \mathrm{kg}$ b.w./day for 30 days and oleanolic acid supplemented group received chromium at the mentioned dose and $\mathrm{OA}$ at a dose of $5 \mathrm{mg} / \mathrm{kg}$ b.w./day orally for past 2 weeks of chromium exposure. 
Table 3: Counteractive effect of OA on Cr (VI) induced alteration in reduced glutathione (GSH) and oxidized glutathione (GSSG) contents, total glutathione/oxidized glutathione (TG: GSSG) ratio, lipid peroxidation (LPO) level and free hydroxyl radical generation in mice brain

\begin{tabular}{llllll}
\hline Groups of animals (n=18) & $\begin{array}{l}\text { GSH ( } \mu \text { moles/ } \\
\text { mg protein) }\end{array}$ & $\begin{array}{l}\text { GSSG }(\mu \text { moles/ } \\
\text { mg protein) }\end{array}$ & TG: GSSG ratio & LPO (nmoles MDA/g tissue) & $\begin{array}{l}\text { Free OH radical } \\
(\mu \text { moles/g tissue) }\end{array}$ \\
\hline Control $(\mathrm{n}=6)$ & $59.86 \pm 1.51$ & $29.62 \pm 0.97$ & $3.02 \pm 0.05$ & $20.13 \pm 0.62$ & $12.4 \pm 0.68$ \\
Cr-treated $(\mathrm{n}=6)$ & $35.23 \pm 1.53^{\mathrm{pa} * * *}$ & $58.93 \pm 0.84 \mathrm{p}^{\mathrm{a} * * *}$ & $1.59 \pm 0.03 \mathrm{p}^{\mathrm{a} * * *}$ & $31.37 \pm 0.98^{\mathrm{pa} * * *}$ & $27.08 \pm 0.73^{\mathrm{pa} * * *}$ \\
OA-Supplemented $(\mathrm{n}=6)$ & $54.61 \pm 1.29^{\mathrm{p} \mathrm{b} * * *}$ & $42.3 \pm 1.46 \mathrm{p}^{\mathrm{b} *}$ & $2.29 \pm 0.06 \mathrm{p}^{\mathrm{b} * * *}$ & $23.73 \pm 0.85^{\mathrm{p} \mathrm{*} * *}$ & $19.03 \pm 0.79^{\mathrm{pb} * * *}$ \\
\hline
\end{tabular}

Figures in the parentheses indicate number of animals in each group $(\mathrm{n}=6)$. $\mathrm{N}$ represents total number of animals. Values are expressed as Means \pm SEM. pa compared to control group and pb compared with $\mathrm{Cr}$-treated group. ${ }^{*} \mathrm{p}<0.05 ;{ }^{* *} \mathrm{p}<0.01$ and ${ }^{* * *} \mathrm{p}<0.001$ are considered statistically significant. Control group received drinking water only, Cr-treated group was treated with hexavalent chromium at a dose of $10 \mathrm{mg} / \mathrm{kg}$ b.w./day for a period of thirty days and oleanolic acid supplemented group received chromium at the mentioned dose and $\mathrm{OA}$ at a dose of $5 \mathrm{mg} / \mathrm{kg}$ b.w./day orally for last two weeks of chromium exposure.

Table 4: Protective effect of $\mathrm{OA}$ on $\mathrm{Cr}$ (VI) induced changes in catalase (CAT), superoxide dismutase (SOD), glutathione reductase (GR) and glutathione peroxidase (GPx) activities in mice brain

\begin{tabular}{lllll}
\hline $\begin{array}{l}\text { Groups of animals } \\
(\mathbf{n}=\mathbf{1 8})\end{array}$ & $\begin{array}{l}\text { CAT activity }\left(\mu \text { moles } \mathbf{H}_{2} \mathbf{O}_{2}\right. \\
\text { hydrolyzed } / \mathbf{m i n} / \mathbf{m g} \text { protein) }\end{array}$ & $\begin{array}{l}\text { SOD activity } \\
(\mathbf{U} / \text { mg protein) }\end{array}$ & $\begin{array}{l}\text { GR activity (nmoles NADPH } \\
\text { oxidized/min/mg protein) }\end{array}$ & GPx activity \\
\hline Control $(\mathrm{n}=6)$ & $118.98 \pm 1.65$ & $2.96 \pm 0.08$ & $99.55 \pm 1.75$ & $117.07 \pm 2.12$ \\
Cr-treated $(\mathrm{n}=6)$ & $87.11 \pm 1.61 \mathrm{p}^{\mathrm{a} * *}$ & $1.72 \pm 0.051 \mathrm{p}^{\mathrm{a} * * *}$ & $45.75 \pm 1.63 \mathrm{p}^{\mathrm{a} * * *}$ & $72.97 \pm 1.86 \mathrm{p}^{\mathrm{a} * *}$ \\
OA-Supplemented $(\mathrm{n}=6)$ & $107.14 \pm 2.74 \mathrm{p}^{\mathrm{b} * *}$ & $2.27 \pm 0.08 \mathrm{p}^{\mathrm{b} * *}$ & $73.05 \pm 1.5 \mathrm{p}^{\mathrm{b} * *}$ & $91.78 \pm 1.67 \mathrm{p}^{\mathrm{b} * *}$ \\
\hline
\end{tabular}

Figures in the parentheses indicate number of animals in each group $(n=6)$. N represents total number of animals. Values are expressed as Means \pm SEM. pa compared to control group, pb compared with Cr-treated group. ${ }^{* *} \mathrm{p}<0.01$ and ${ }^{* * *} \mathrm{p}<0.001$ are considered statistically significant. Control group received drinking water only, Cr-treated group was treated with hexavalent chromium at a dose of $10 \mathrm{mg} / \mathrm{kg}$ b.w./day for a period of thirty days and $0 \mathrm{~A}$ supplemented group received chromium at the mentioned dose and $\mathrm{OA}$ at a dose of $5 \mathrm{mg} / \mathrm{kg}$ b.w./day orally for last two weeks of chromium exposure.

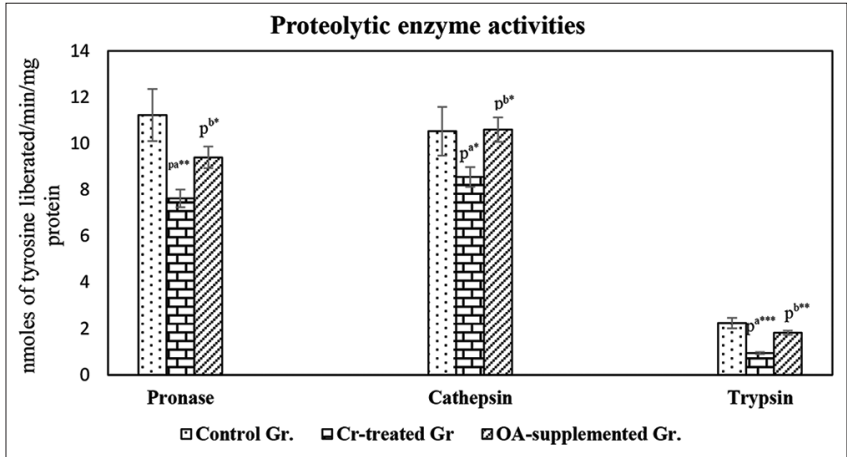

Fig. 5: Restorative effect of $\mathrm{OA}$ against $\mathrm{Cr}$ (VI) induced decreased brain proteolytic enzyme activities. Values were expressed as Means \pm SEM. Each bar represents mean value of data from six numbers of mice. Asterisk indicated significant difference. pa compared with control group, pb compared with chromium treated group. ${ }^{* *}$ Represented $\mathbf{p}<0.01$ and ${ }^{*}, \mathrm{p}<0.05$

lipid peroxides in mice brain. The counteraction was found to be $24 \%$ $(\mathrm{p}<0.01)$. Free hydroxyl radical production was markedly increased in chromium intoxicated mice brain $(118 \%, \mathrm{p}<0.001)$. Oleanolic acid also restored the free hydroxyl radical toward normalcy (Table 3).

Moreover, both the catalase and SOD activities were inhibited in mice brain after exposure to hexavalent chromium (Table 4). The inhibition was noted as $26.78 \%(\mathrm{p}<0.01)$ in case of the catalase, and $42 \%(\mathrm{p}<0.001)$ in case of the SOD activity. Oleanolic acid supplementation showed significant protective effect in restoration of these two potential antioxidant enzyme activities toward their respective control values. Other than these, GR and GPx activities were also significantly inhibited by hexavalent chromium exposure at the present dose and duration. The decrease was recorded as $54 \%(\mathrm{p}<0.001)$ and $37.7 \%(\mathrm{p}<0.01)$. Oleanolic acid supplementation partially counteracted both of the GR and GPx activities toward normalcy.

\section{DISCUSSION}

Significant disorientation in metabolic homeostasis in the brain tissue of mice was observed after 30 days of hexavalent chromium exposure at sub-acute dose. $\mathrm{Cr}(\mathrm{VI})$, being a non-biodegradable toxicant, penetrates the organisms through inhalation, drinking water and incidental ingestion and thus affects crucial bio-molecules and enzymatic functions [44]. In the present study, $\mathrm{Cr}$ (VI) treatment appeared to have no significant effect on the body weight of experimental mice, indicating that gain in the body weight was independent of chromium exposure at the present dose and duration, but moderate increase in cerebro-somatic index (CSI) was observed during post-sacrifice examination. This might be due to over accumulation of elemental chromium in the brain tissue of mice as evidenced by the present study. Bio-magnification of $\mathrm{Cr}$ generally occurs in the organisms by occupational, environmental or accidental exposure [45] that accounts for the toxic effect on the specific tissue of exposed animals. Metabolic perturbation is proposed to be one of the toxic manifestations of hexavalent chromium which may contribute to functional abnormalities of the cell. The present study elucidated significant alteration of glycolytic and TCA cycle intermediates as well as certain protein metabolites after chromium exposure and also signified the role of oleanolic acid, a plant-based pentacyclic triterpenoid, in protection of that metabolic imbalance caused by hexavalent chromium.

A remarkable decrease in pyruvic acid content in mice brain was noted after hexavalent chromium treatment, which might be due to less supply of glucose to the cerebral tissue via circulation during chromium toxicity. This is supported by the fact that chromium exposure at that dose and duration produced hypoglycemia [20] that might aid less substrate like glucose to the brain tissue for its metabolism. Adjustment of the bio-energetic fluxes in different tissues might result from malfunctioning of those proteins directly involved in the metabolic pathways or due to altered substrate availability in those tissues [46]. Within the cellular environment, hexavalent chromium may be reduced to trivalent $\mathrm{Cr}$-ATP complex, the later acts as a competitive inhibitor for various ATP dependent enzymes and several kinases involved in glycolysis as well as TCA cycle $[46,47]$. Consequently, this might slow down the rate of glycolysis, leading to less production of pyruvic acid. This is supported by the earlier observation where decreased glycolytic activity in hepatic tissue was observed after chromium exposure [20]. It was further suggested that glucagon hormone, secreted in response to hypoglycemia, inhibited hepatic L-isozyme of the pyruvate kinase thus induced retardation of glycolytic activity in that tissue [47]. Similar explanation may also be suggested for chromium-induced retardation of brain glycolytic activity. 
On the other hand, hexavalent chromium exposure at the present dose and duration exhibited significant effect on brain TCA cycle enzyme activities. The MDH activity in the brain tissue of mice was significantly decreased after $\mathrm{Cr}$ (VI) exposure. This enzyme not only helps in providing energy through TCA cycle but also aids in gluconeogenesis to produce glucose from the non-carbohydrate source [48]. Suppressed mitochondrial MDH activity in brain tissue by $\mathrm{Cr}$ (VI) indicated slow metabolic conversion of malate to oxaloacetate in the TCA cycle, thus paid to low energy state in the cerebral tissue in consequence of toxic manifestation [49]. Inadequate reimbursement by fermentation and inhibition of cellular respiration by hexavalent $\mathrm{Cr}$ (VI) perturbed the nucleotide pool and ultimately obliterated the energy homeostasis in $\mathrm{Cr}$ (VI) intoxicated organs [49]. In addition, reduced glucose supply to brain tissue might also contribute to less production of glycolytic intermediates like pyruvic acid resulting in impairment of energy yielding mechanism and consequent brain dysfunctions after $\mathrm{Cr}$ (VI) intoxication. Moreover, mitochondrial dehydrogenases such as NADH dehydrogenase (mitochondrial complex I) and succinate dehydrogenase (mitochondrial complex II) were significantly inhibited by hexavalent chromium at the present dose and duration. These might lead to exhaustion of NADH pool in the stressed tissue [50] and caused subsequent deterioration of mitochondrial energy production. Consequently, energy deficient brain tissue might proceed through the anaerobic process following $\mathrm{Cr}(\mathrm{VI})$ treatment. That impairment of the SDH activity by $\mathrm{Cr}$ (VI) was also evident from the earlier observation in hepatic tissue of mice $[20,51]$.

Tissue protein content and proteolytic enzyme activities such as pronase, cathepsin, and trypsin were declined in cerebral tissue due to Cr (VI) toxicity. Reduction of protein in other biological samples such as plasma by sub-acute dose of hexavalent chromium was reported earlier [52]. Protein depletion in the tissue designated for physiological adjustment in response to the changed metabolic situation that might lead to stimulation of proteolysis and utilization of protein degradation products for energy metabolism. Protein depletion might also be due to oxidative degeneration of native proteins by heavy metals or metalloids like chromium. This is supported by the earlier study of Das and Pal [53], which revealed that lead $(\mathrm{Pb})$ caused enhancement of carbonylated protein content within hepatic and skeleto-muscular tissue, thereby modulated protein metabolic efficacy of those tissues. Similar observation was also noted in the present study where chromium exposure significantly elevated carbonylated protein content in the brain tissue of mice. In addition, heavy metals also induce abnormal glycosylation of tissue proteins [54]. Uncharacterized glycosylated or post-translated proteins lose their ability to achieve programmed function of cellular integrity [55] and may thereby encourage tissue metabolic disorders. Breakdown of tissue protein in consequence of hexavalent chromium toxicity increased the free amino acid nitrogen content in other tissues too [56]. The present study further established that the sub-acute $\mathrm{Cr}$ (VI) exposure elevated free amino nitrogen content in the cerebral tissue significantly. That increased level of free amino acid nitrogen might be due to mobilization of free amino acids through the circulation to meet the demand of energy or to provide substrates for the synthesis of new proteins to cope up with the repairmen of intoxicated nervous tissue due to $\mathrm{Cr}(\mathrm{VI})$ toxicity. The present study is in conformity with the previous report of Shil and Pal [56], which revealed a remarkable decrease in total protein content with increased activities of transaminases such as GOT and GPT in hepatic and muscular tissue of $\mathrm{Cr}(\mathrm{VI})$ treated animals. Increased availability of substrates like free amino acids might contribute to enhanced transaminase activities to promote gluconeogenesis to compensate hypoglycemia as suggested by earlier reporters [56]. Moreover, increased transaminase activities indicated degenerative changes in the brain tissue of mice which might promote leakage of intracellular enzymes and other metabolites.

The present study further depicted that the activities of important proteases such as trypsin, cathepsin, and pronase in mice brain were decreased after sub-acute $\mathrm{Cr}$ (VI) exposure. Cathepsin and pronase are the vital lysosomal proteolytic enzymes that accomplish protein degradation and facilitate enrichment of amino acid pool in various tissues for maintaining crucial metabolic attributes such as cellular repair, energy generation, and utilization of degraded products. It was already established that hepatic and muscular proteins and proteolytic enzymes were sensitive to hexavalent chromium poisoning [56]. $\mathrm{Cr}$ (VI), being a toxic metalloid, was widely suspected to impose organ toxicity, genotoxicity, chromosomal aberration, mutational changes and DNA-DNA cross strand, which might prevent enzyme synthesis or might enhance depletion of metabolic intermediates from the respective tissue [57]. Less availability of specific substrates in the experimental tissue might be one of the causative factors of $\mathrm{Cr}$ (VI) induced retardation of proteolytic enzyme activities. Alteration in physicochemical properties of proteins might be involved in excess production of reactive oxygen species, and $\mathrm{Cr}(\mathrm{VI})$, being a free radical generator [10], encouraged oxidative stress mechanism. These in turn might cause reduced level of desired tissue proteins for proteolytic enzyme actions. Enhanced formation of carbonylated proteins in the cerebral tissue of mice might explain oxidative stress mediated damage of functional proteins, and its less availability for normal tissue metabolic activities. Thus, short-term exposure of $\mathrm{Cr}$ (VI) exhibited significant impact on brain metabolic activities by modulating certain important enzymes and basic parameters of protein metabolism.

In addition, hexavalent chromium had been reported to modify oxidative stress parameters in different organ systems [58,59]. It was found to reduce brain glutathione (GSH) content in association with enhanced oxidized glutathione (GSSG) level, lipid peroxide and free hydroxyl radical formation at the present dose and duration. Within the cellular environment, hexavalent chromium was reduced to trivalent form by different reducing agents; GSH was one of them [60]. So, Cr (VI) used to utilize GSH for its own metabolism and thereby decreased intracellular GSH pool. During that process free hydroxyl radicals were generated which might lead to DNA strand break [60]. As glutathione normally helps in protection of tissue from oxidative damage, depletion of this endogenous antioxidant promotes oxidative stress and damages cellular macromolecules such as DNA, protein, and lipids. Over production of free hydroxyl radicals was also found in the current experimental setup after hexavalent chromium intoxication, which might contribute to damage of cellular proteins and lipids. Elevation of brain tissue oxidized glutathione (GSSG), an indicative marker of oxidative stress, was pronounced in the chromium exposed animals (Table 3). This might be due to decreased activities of glutathione reductase and glutathione peroxidase in the experimental tissue of mice after hexavalent chromium exposure. As a result, the total glutathione and oxidized glutathione ratio (TG: GSSG) was also significantly decreased in chromium-treated mice brain, indicating imbalance in production and deposition of reactive oxygen species (ROS). Malondialdehyde, a marker of lipid peroxidation was more in concentration in the $\mathrm{Cr}(\mathrm{VI})$-treated mice, as observed in the present study. This is in conformity with the earlier reports [58,61]. Brain tissue, due to its high content of polyunsaturated fatty acids and high oxygen consumption, is susceptible to oxidative stress, and thus pay to tissue degenerative changes. In addition, hexavalent chromium was found to inhibit certain antioxidant enzyme activities such as catalase, SOD, glutathione reductase and glutathione peroxidase at the present dose and duration. Changes in antioxidant enzymes in different animal cells by hexavalent chromium were observed in earlier studies $[62,63]$. Inhibition of those antioxidant enzymes by chromium increased the chance for generation of superoxide radicals and hydrogen peroxide which promoted oxidative brain tissue damage.

To minimize the adverse effects of hexavalent chromium, several natural and synthetic antioxidants had been tried. Among them plant polyphenols gained attention for the decades due to their potential therapeutic effects without having major side effects. Oxidative stress and apoptotic changes in lung epithelial cells by hexavalent chromium were prevented by apple juice [64]. It was reported that quercetin, a dietary flavonoid as a protective agent against $\mathrm{Cr}$ (VI) mediated malignant cell transformation and ROS production [65]. 
Phytochemicals from Eugenia dysenterica leaf extract was found to have antioxidant property against $\mathrm{Cr}$ (VI)-induced oxidative stress and cytotoxicity [66]. Moreover, chemo-preventive effect of green tea extract against $\mathrm{Cr}(\mathrm{VI})$-induced genotoxicity was also evaluated earlier [67]. In addition, curcumin, rutin, alpha-tocopherol, vitamin $\mathrm{C}, \mathrm{N}$-acetylcysteine, ginger, and vitamin $\mathrm{E}$ were reported to have chemo-preventive properties against $\mathrm{Cr}$ (VI)-induced genotoxicity or carcinogenicity [68]. The present study further evaluated the protective efficacy of oleanolic acid, isolated from N. wightiana, a medicinal plant collected from the South district of Tripura, North East India against hexavalent chromium toxicity. This chemical compound is a triterpenoid having antioxidant property. OA supplementation in Cr (VI)-treated mice appreciably counteracted chromium-induced decreased pyruvic acid content, elevated free amino acid nitrogen and transaminase enzyme activities such as GOT and GPT. It was found that OA partially checked over deposition of elemental chromium within the brain tissue of mice and thus moderately reduced the cerebro-somatic index. A healthy tissue can fight better against any toxicant mediated damage and give protection to diseases. Beneficial effects of oleanolic acid against sodium fluoride-induced brain metabolic dysfunctions and nucleic acid depletion were investigated earlier [13]. OA was found to have almost similar efficacy as vitamin $\mathrm{C}$ in restoration of DNA and RNA contents and free amino acid nitrogen level in different brain regions of rat as evidenced by their studies. Moreover, antioxidant power of OA was found to be comparable with other commercial antioxidants by using ferric reducing antioxidant power (FRAP), 1,1-diphenyl-2picrylhydrazyl (DPPH) and lipid peroxidation inhibition assays [69].

It was further observed that $\mathrm{OA}$ appreciably counteracted the decreased TCA cycle enzyme activities such as MDH, SDH as well as mitochondrial NADH dehydrogenase enzyme function. These might help in energizing the brain cells of mice to restore its normal metabolic functioning that was threatened by hexavalent chromium. These might be due to protective effect of $\mathrm{OA}$ on antioxidant defence system of the brain tissue and certain drug metabolizing enzymes that neutralize the harmful effects of chromium on the experimental animals. This is supported by the earlier observation [70], which revealed appreciable beneficial effect of $\mathrm{OA}$ against ethanol-induced hepatotoxicity by stimulating certain antioxidant and drug metabolizing enzymes. In addition, neuroprotective functions of this triterpenoid were evaluated in the frontal cortex and hippocampus of mice brain in terms of release of brain derived neurotropic factor and few neurotransmitters [71]. $\mathrm{OA}$, being an antioxidant, exhibited significant amelioration against hexavalent chromium-induced alteration in oxidative damage of proteins to reduce the elevated level of carbonylated protein content in chromium exposed cerebral tissue of mice. Earlier investigation revealed remarkable protective effect of oleanolic acid pre-treatment to check lipid peroxidation and to stimulate antioxidant enzyme functions that were disturbed by ischemic injury [72]. The present study further exhibits that depleted reduced glutathione content was restored appreciably, whereas increased oxidized glutathione content, free hydroxyl radical production and malonaldehyde level were counteracted by OA supplementation, indicating potential antioxidant efficacy of $\mathrm{OA}$ against hexavalent chromium induced oxidative stress. In addition, decreased total glutathione/oxidized glutathione ratio by chromium was also partially restored by $\mathrm{OA}$ supplementation. Moreover, the inhibitory effects of hexavalent chromium on potential antioxidant enzyme activities such as SOD, catalase, glutathione reductase, and glutathione peroxidase were partially withdrawn by $\mathrm{OA}$ supplementation at the present dose and duration. These observations are in conformity with the several earlier studies where OA was used as an ethno-medicine to minimize the complications of oxidative injury mediated diseases [73]. An in vitro study established increased the production of glutathione and the expression of key antioxidant enzymes by OA [74]. Antioxidative properties of OA in different brain regions of rats were evaluated earlier against sodium fluoride-induced oxidative and metabolic dysfunctions [13]. Such protective effects of OA might also be helpful in restoration of suppressed proteolytic enzyme activities like pronase, trypsin and cathepsin following hexavalent chromium exposure. Partial restoration of total protein content in mice brain by $\mathrm{OA}$ was co-operative in maintaining the substrate availability for normal functioning of the proteases. Thus, OA supplementation exhibited significant counteractive effects against Cr (VI) induced metabolic and oxidative dysfunctions in mice brain.

\section{CONCLUSION}

The current observation was made on ethno-medicinal efficacy of oleanolic acid, a pentacyclic triterpenoid, isolated from N. wightiana, against hexavalent chromium induced brain metabolic and oxidative stress. Cr (VI) exposure at sub-acute dose for a period of thirty days produced diminution of pyruvic acid content in brain tissue indicating retardation of glycolytic activity in that tissue. In addition, $\mathrm{Cr}$ (VI) exposure significantly altered the TCA cycle enzyme activities through suppression of MDH, SDH, and NADH dehydrogenase activities showing impairment of energy production through mitochondrial respiratory chain. Moreover, protein depletion was also an important adverse effect of $\mathrm{Cr}$ (VI) toxicity. Alteration in proteolytic enzyme activities such as trypsin, cathepsin, and pronase was in accordance with the availability of their specific substrates. Enhanced transamination was associated with excess production of free amino acid nitrogen in chromium stressed brain tissue. It is suggested that a compensatory adjustment in between carbohydrate and protein metabolites was initiated after shortterm chromium exposure that may aid glucose from non-carbohydrate source such as protein to meet the demand of energy in $\mathrm{Cr}(\mathrm{VI})$ stressed brain tissue. In addition, perturbation of endogenous antioxidants and antioxidant enzymes along with over production of lipid peroxides and free hydroxyl radicals is the underlying mechanism of oxidative stress, induced by hexavalent chromium toxicity. Oleanolic acid appreciably checked chromium-induced metabolic and oxidative anomalies and restored crucial metabolites and enzyme activities including MDH, SDH, NADH dehydrogenase, transaminases, proteases, SOD, catalase, GR and GPx toward normalcy. Thus, OA may serve as a prospective protective agent against hexavalent chromium induced metabolic and oxidative dysfunctions in mice brain.

\section{ACKNOWLEDGMENT}

The author acknowledges the Co-ordinator, State Biotech Hub, Tripura University for providing instrumental facility to carry out the present work. I am thankful to the H.O.D, department of Human Physiology to use the laboratory and chemicals from the departmental facility. The author is also thankful to the Chairman, Pollution Control Board, Tripura for giving permission to use the atomic absorption spectrophotometer for metal detection. I am also thankful to Dr. Kanu Shil for his support in partial evaluation of data.

\section{AUTHOR'S CONTRIBUTION}

The author has made substantial contribution to carry out the present work. The concept, design of the study, evaluation of raw data and whole write up of the manuscript are made by the author in her own capacity.

\section{CONFLICT OF INTEREST}

There is no conflict of interest.

\section{AUTHOR'S FUNDING}

The present work is self-financed. No funding agency is involved in the present work.

\section{REFERENCES}

1. Chou TC, Wang PC, Wu JD, Sheu SC. Chromium-induced skin damage among Taiwanese cement workers. Toxicol Ind Health 2016;32:1745-51.

2. Barceloux DG. Chromium. J Toxicol Clin Toxicol 1999;37:173-94.

3. Marouani N, Tebourbi O, Hallègue D, Mokni M, Yacoubi MT, Sakly M, et al. Mechanisms of chromium hexavalent-induced apoptosis in rat testes. Toxicol Ind Health 2017;33:97-106. 
4. Li P, Li Y, Zhang J, Yu SF, Wang ZL, Jia G. Establishment of a reference value for chromium in the blood for biological monitoring among occupational chromium workers. Toxicol Ind Health 2016;32:1737-44.

5. Jacobs JA, Testa SM. Overview of chromium (VI) in the environment: Background and history. In: Guertin J, Jacobs JA, Avakia CP, editors. Chromium (VI). USA: CRC Press; 2005. p. 1-22.

6. Wilbur S, Abadin H, Fay M, Yu D, Tencza B, Ingerman L, et al. Toxicological Profile for Chromium. Atlanta, GA: Agency for Toxic Substances and Disease Registry; 2012

7. Valko M, Morris H, Cronin MT. Metals, toxicity and oxidative stress. Curr Med Chem 2005;12:1161-208.

8. Bagchi D, Balmoori J, Bagchi M, Ye X, Williams CB, Stohs SJ. Comparative effects of TCDD, endrin, naphthalene and chromium (VI) on oxidative stress and tissue damage in the liver and brain tissues of mice. Toxicol 2002;175:73-82.

9. Singh P, Chowdhuri DK. Environmental presence of hexavalent but not trivalent chromium causes neurotoxicity in exposed drosophila melanogaster. Mol Neurobiol 2017;54:3368-87.

10. Quinteros FA, Poliandri AH, Machiavelli LI, Cabilla JP, Duvilanski BH. In vivo and in vitro effects of chromium VI on anterior pituitary hormone release and cell viability. Toxicol Appl Pharmacol 2007;218:79-87.

11. Pan TL, Wang PW, Chen CC, Fang JY, Sintupisut N. Functional proteomics reveals hepatotoxicity and the molecular mechanisms of different forms of chromium delivered by skin administration. Proteomics 2012;12:477-89.

12. Xiao F, Feng X, Zeng M, Guan L, Hu Q, Zhong C. Hexavalent chromium induces energy metabolism disturbance and p53-dependent cell cycle arrest via reactive oxygen species in L-02 hepatocytes. Mol Cell Biochem 2012;371:65-76.

13. Sarkar C, Pal S, Das N, Dinda B. Ameliorative effects of oleanolic acid on fluoride induced metabolic and oxidative dysfunctions in rat brain: Experimental and biochemical studies. Food Chem Toxicol 2014;66:224-36.

14. Liu Y, Hartley DP, Liu J. Protection against carbon tetrachloride hepatotoxicity by oleanolic acid is not mediated through metallothionein. Toxicol Lett 1998;95:77-85.

15. Ayeleso TB, Matumba MG, Mukwevho E. Oleanolic Acid and its derivatives: Biological activities and therapeutic potential in chronic diseases. Molecules 2017;22:1915.

16. Bednarczyk-Cwynar B, Zaprutko L, Marciniak J, Lewandowski G, Szulc M, Kaminska E, et al. The analgesic and anti-inflammatory effect of new oleanolic acid acyloxyimino derivative. Eur J Pharm Sci 2012;47:549-55.

17. Kim S, Lee H, Lee S, Yoon Y, Choi KH. Antimicrobial action of oleanolic acid on Listeria monocytogenes, Enterococcus faecium, and Enterococcus faecalis. PLoS One 2015;10:e0118800.

18. Yin MC, Chan KC. Nonenzymatic antioxidative and antiglycative effects of oleanolic acid and ursolic acid. J Agric Food Chem 2007;55:7177-81.

19. Das N, Ghosh PS, Das MC, Dinda B. A new biologically active triterpenoid saponin from the aerial parts of Neanotis wightiana. Phytochem Lett 2013;6:270-3

20. Shil K, Pal S. Hexavalent chromium induced alteration of carbohydrate bioenergetics: A dose-dependent study. Asian J Pharm Clin Res 2017;10:410-7.

21. Shil K, Pal S. Metabolic adaptability in hexavalent chromium-treated renal tissue: An in vivo study. Clin Kidney J 2018;11:222-9.

22. Lee J, Lim KT. Inhibitory effect of SJSZ glycoprotein $(38 \mathrm{kDa})$ on expression of heat shock protein 27 and 70 in chromium (VI)-treated hepatocytes. Mol Cell Biochem 2012;359:45-57.

23. Dutta M, Bandyopadhyay D, Chattopadhyay A, Bose G, Ghosh A, Banerjee A, et al. Aqueous bark extract of Terminalia arjuna protects against high fat diet aggravated arsenic-induced oxidative stress in rat heart and liver, involvement of antioxidant mechanisms. J Pharm Res 2014;8:1285-302.

24. Krishnaiah C, Reddy KP. Dose-dependent effects of fluoride on neurochemical milieu in the hippocampus and neocortex of rat brain. Fluoride 2007;40:101-10.

25. Segal S, Blair AE, Wyngaarden JB. An enzymatic spectrophotometric method for the determination of pyruvic acid in blood. J Lab Clin Med 1956;48:137-43.

26. Mehler AH, Kornberg A, Grisolia S, Ochoa S. The enzymatic mechanism of oxidation reductions between malate or isocitrate and pyruvate. J Biol Chem 1848;174:961-77.

27. Minakami S, Ringler RL, Singer TP. Studies on the respiratory chainlinked dihydrodiphosphopyridine nucleotide dehydrogenase. I. Assay of the enzyme in particulate and in soluble preparations. J Biol Chem
1962;237:569-76

28. Stadtman ER, Levine RL. Protein oxidation. Ann N Y Acad Sci 2000;899:191-208

29. Rosen H. A modified ninhydrin colorimetric analysis for amino acids. Arch Biochem Biophys 1957;67:10-5.

30. Barman TE. Enzyme Hand Book. New York: Springer-Verlag; 1974.

31. Green NM, Work E. Pancreatic trypsin inhibitor. II. Reaction with trypsin. Biochem J 1953;54:347-52.

32. Pokrovsky AA, Archakov AI, Lyubimtseva ON, Strove EA, Makarova VO. Laboratory Manual in Biochemistry. Moscow: Mir Publishers; 1989.

33. Reitman S, Frankel S. A colorimetric method for the determination of serum glutamic oxalacetic and glutamic pyruvic transaminases. Am J Clin Pathol 1957;28:56-63.

34. Davila JC, Davis PJ, Acosta D. Changes in glutathione and cellular energy as potential mechanisms of papaverine-induced hepatotoxicity in vitro. Toxicol Appl Pharmacol 1991;108:28-36.

35. Mohan T, Narasimhan KK, Ravi DB, Velusamy P, Chandrasekar N, Chakrapani LN, et al. Role of Nrf2 dysfunction in the pathogenesis of diabetic nephropathy: Therapeutic prospect of epigallocatechin-3gallate. Free Radic Biol Med 2020;160:227-38.

36. Buege JA, Aust SD. Microsomal lipid peroxidation. Methods Enzymol 1978:52:302-10.

37. Babbs CF, Steiner MG. Detection and quantitation of hydroxyl radical using dimethyl sulfoxide as molecular probe. Methods Enzymol 1990;186:137-47.

38. Aebi H. Catalase in vitro. Methods Enzymol 1984;105:121-6.

39. Martin JP Jr., Dailey M, Sugarman E. Negative and positive assays of superoxide dismutase based on hematoxylin autoxidation. Arch Biochem Biophys 1987;255:329-36.

40. Carlberg I, Mannervik B. Glutathione reductase. Methods Enzymol 1985;113:484-90.

41. Maiti S, Chatterjee AK. Differential response of cellular antioxidant mechanism of liver and kidney to arsenic exposure and its relation to dietary protein deficiency. Environ Toxicol Pharmacol 2000;8:227-35.

42. Lowry OH, Rosebrough NJ, Farr AL, Randall RJ. Protein measurement with the Folin phenol reagent. J Biol Chem 1951;193:265-75.

43. Sun Z, Liang P. Determination of $\mathrm{Cr}$ (III) and total $\mathrm{Cr}$ (VI) in water samples by cloud point extraction and flame atomic absorption spectrometry. Microchim Acta 2008;162:121-5.

44. Soudani N, Rafrafi M, Ben Amara I, Hakim A, Troudi A, Zeghal KM, et al. Oxidative stress-related lung dysfunction by chromium (VI): Alleviation by Citrus aurantium L. J Physiol Biochem 2013;69:239-53.

45. Batvari BP, Sivakumar S, Shanthi K, Lee KJ, Oh BT, Krishnamoorthy RR, et al. Heavy metals accumulation in crab and shrimps from Pulicat Lake, north Chennai coastal region, southeast coast of India. Toxicol Ind Health 2016;32:1-6.

46. Lippard SJ, Berg JM. Principles of Bioinorganic Chemistry. Herdon, USA: University Science Books; 1997.

47. Myers JM, Antholine WE, Myers CR. The intracellular redox stress caused by hexavalent chromium is selective for proteins that have key roles in cell survival and thiol redox control. Toxicology 2011:281:37-47.

48. Bianchi V, Debetto P, Zantedeschi A, Levis AG. Effects of hexavalent chromium on the adenylate pool of hamster fibroblasts. Toxicology 1982;25:19-30.

49. Abreu PL, Ferreira LM, Alpoim MC, Urbano AM. Impact of hexavalent chromium on mammalian cell bioenergetics: Phenotypic changes, molecular basis and potential relevance to chromate-induced lung cancer. Biometals 2014;27:409-43.

50. Ryberg D, Alexander J. Mechanisms of chromium toxicity in mitochondria. Chem Biol Interact 1990;75:141-51.

51. Molina-Jijón E, Tapia E, Zazueta C, El Hafidi M, Zatarain-Barrón ZL, Hernández-Pando R, et al. Curcumin prevents Cr (VI)-induced renal oxidant damage by a mitochondrial pathway. Free Radic Biol Med 2011;51:1543-57.

52. Kori-Siakpere O, Ake JE, Avworo UM. Sub-lethal effects of Cadmium on some selected haematological parameters of Heteroclarias: A hybrid of Heterobranchus bidorsalis and Clarias gariepinus. Int J Zool Res 2006;2:77-83

53. Das $\mathrm{P}, \mathrm{Pal} \mathrm{S}$. Lead $(\mathrm{Pb})$, a threat to protein metabolic efficacy of liver, kidney and muscle in mice. Comp Clin Pathol 2017;26:875-83.

54. Ramamurthy CH, Subastri A, Suyavaran A, Subbaiah KC, Valluru L, Thirunavukkarasu C. Solanum torvum Swartz. fruit attenuates cadmium-induced liver and kidney damage through modulation of oxidative stress and glycosylation. Environ Sci Pollut Res Int 2016;23:7919-29. 
55. Peharec Štefanić P, Sikić S, Cvjetko P, Balen B. Cadmium and zinc induced similar changes in protein and glycoprotein patterns in tobacco (Nicotiana tabacum L.) seedlings and plants. Arh Hig Rada Toksikol 2012;63:321-35.

56. Shil K, Pal S. Metabolic and morphological disorientations in liver and skeletal muscle of mice exposed to hexavalent chromium. Comp Clin Pathol 2019;28:1729-41.

57. Zhitkovich A. Chromium in drinking water: Sources, metabolism, and cancer risks. Chem Res Toxicol 2011;24:1617-29.

58. Patlolla AK, Barnes C, Yedjou C, Velma VR, Tchounwou PB. Oxidative stress, DNA damage, and antioxidant enzyme activity induced by hexavalent chromium in Sprague-Dawley rats. Environ Toxicol 2009;24:66-73.

59. Kotyzová D, Hodková A, Bludovská M, Eybl V. Effect of chromium (VI) exposure on antioxidant defense status and trace element homeostasis in acute experiment in rat. Toxicol Ind Health 2015;31:1044-50.

60. Balali-Mood M, Naseri K, Tahergorabi Z, Khazdair MR, Sadeghi M. Toxic mechanisms of five heavy metals: Mercury, lead, chromium, cadmium, and arsenic. Front Pharmacol 2021;12:643972.

61. Susa N, Ueno S, Furukawa Y, Michiba N, Minoura S. Induction of lipid peroxidation in mice by hexavalent chromium and its relation to the toxicity. Nihon Juigaku Zasshi 1989;51:1103-10.

62. Kumar P, Kumar R, Nagpure NS, Nautiyal P, Kushwaha B, Dabas A. Genotoxicity and antioxidant enzyme activity induced by hexavalent chromium in Cyprinus carpio after in vivo exposure. Drug Chem Toxicol 2013;36:451-60.

63. Husain N, Mahmood R. Hexavalent chromium induces reactive oxygen species and impairs the antioxidant power of human erythrocytes and lymphocytes: Decreased metal reducing and free radical quenching ability of the cells. Toxicol Ind Health 2017;33:623-35.

64. Shi D, Jiang BH. Antioxidant properties of apple juice and its protection against Cr (VI)-induced cellular injury. J Environ Pathol Toxicol Oncol 2002;21:233-42.

65. Pratheeshkumar P, Son YO, Divya SP, Turcios L, Roy RV, Hitron JA, et al. Hexavalent chromium induces malignant transformation of human lung bronchial epithelial cells via ROS-dependent activation of miR-21-PDCD4 signaling. Oncotarget 2016;7:51193-210.

66. Ávila RI, Mattos Alvarenga CB, Ávila PH, Moreira RC, Arruda AF, Fernandes TO, et al. Eugenia dysenterica DC. (Myrtaceae) exerts chemopreventive effects against hexavalent chromium-induced damage in vitro and in vivo. Pharm Biol 2016;54:2652-63.

67. García-Rodríguez Mdel C, Montaño-Rodríguez AR, AltamiranoLozano MA. Modulation of hexavalent chromium-induced genotoxic damage in peripheral blood of mice by epigallocatechin-3-gallate (EGCG) and its relationship to the apoptotic activity. J Toxicol Environ Health A 2016;79:28-38.

68. Wang Y, Su H, Gu Y, Song X, Zhao J. Carcinogenicity of chromium and chemoprevention: A brief update. Onco Targets Ther 2017;10:4065-79.

69. Ghafoor K. Antioxidant properties. AgroFOOD Ind Hi Tech 2014;25:2.

70. Pollier J, Goossens A. Oleanolic acid. Phytochemistry 2012;77:10-5.

71. Yi LT, Li J, Liu Q, Geng D, Zhou YF, Ke XQ, et al. Antidepressantlike effect of oleanolic acid in mice exposed to the repeated forced swimming test. J Psychopharmacol 2013;27:459-68.

72. Rong ZT, Gong XJ, Sun HB, Li YM, Ji H. Protective effects of oleanolic acid on cerebral ischemic damage in vivo and $\mathrm{H}(2) \mathrm{O}(2)$-induced injury in vitro. Pharm Biol 2011;49:78-85.

73. Gao D, Li Q, Li Y, Liu Z, Fan Y, Liu Z, et al. Antidiabetic and antioxidant effects of oleanolic acid from Ligustrum lucidum Ait in alloxan-induced diabetic rats. Phytother Res 2009;23:1257-62

74. Wang X, Ye XL, Liu R, Chen HL, Bai H, Liang X, et al. Antioxidant activities of oleanolic acid in vitro: Possible role of Nrf2 and MAP kinases. Chem Biol Interact 2010;184:328-37. 